EGU2020-15424

https://doi.org/10.5194/egusphere-egu2020-15424

EGU General Assembly 2020

(c) Author(s) 2021. This work is distributed under

the Creative Commons Attribution 4.0 License.

\title{
Soil organic carbon stock development in chernozemic soils following agricultural abandonment
}

Tibor József Novák, László Márta, and Szabolcs Balogh

University of Debrecen, Institute of Earth Sciences, Department for Landscape Protection and Environmental Geography, Debrecen, Hungary (novak.tibor@science.unideb.hu)

Post agricultural development of traditionally intensively cultivated high fertility soils is a relevant question in surroundings of towns affected by urban sprawl, where extent areas of former cultivated soils are converted into residential, industrial or infrastructural surfaces. Part of these areas will covered by artificially sealed soils, but always extent areas remain for green areas, managed with different intensity, which allows recharge of soil organic carbon stocks and soil regeneration processes. In our study agricultural and post agricultural soils were sampled in a Chernozemic landscape affected by urbanization processes. Besides of other regeneration processes, concerning to the improvement of soil structure, we found that soil organic carbon stocks in the $0-30 \mathrm{~cm}$ soil layer are significantly higher in post agricultural soils $\left(9.4 \pm 0.5 \mathrm{~kg} \cdot \mathrm{m}^{-2}\right)$ as in ploughed $\left(6.4 \pm 0.8 \mathrm{~kg} \cdot \mathrm{m}^{-2}\right)$ or in ploughed plus irrigated $\left(5.6 \pm 0.7 \mathrm{~kg} \cdot \mathrm{m}^{-2}\right)$ profiles. The difference was found to be significant not only until the depth of the cultivated layer $(30 \mathrm{~cm})$, but until the sampled $70 \mathrm{~cm}$ depth throughout $\left(17.8 \pm 0.9 ; 10.8 \pm 3.3\right.$ and $10.6 \pm 2.7 \mathrm{~kg} \cdot \mathrm{m}^{-2}$ respectively). Our results point on the high carbon recovery potential of suburban areas converted from fertile cultivated soils. 